DOI https://doi.org/10.18551/rjoas.2016-10.06

\title{
ECONOMICS OF NON-OIL EXPORTS OF SUDAN
}

\author{
Elkhatim Asma Khalifa \\ University of Khartoum, Sudan \\ E-mail: asmakhalifa85@yahoo.com
}

\begin{abstract}
The purpose of this paper was to estimate the respective roles of oil and non-oil exports to total Sudan exports during 1970-2009. The specific objective aimed to estimate the respective role of agricultural exports on the agricultural Gross Domestic Product (GDP) and the main factors affecting the exports of selected agricultural commodities. The study ultilized secondary data covering the period 1970-2009. The data analyzed using descriptive analysis and multiple regression analysis. The main finding of study showed that the contribution of agricultural exports to total exports dropped from 100\% during 1990-1994 to $8.5 \%$ during 2005-2009. The study also indicated that the increased revenues of oil exports caused a positive trade balance in certain years. The main agricultural exports were sesame $32.3 \%$ of total agricultural value, sheep $21.8 \%$, cotton $17.7 \%$ and gum Arabic $14.8 \%$. As an example, the regression results indicated a negative relationship between the FOB prices and quantities exported in the case of sesame export model. It also showed the existence of a positive relationship between production and exports of sesame. In case of gum Arabic model the results indicated positive relationship between exports of gum Arabic and production, stock, and negative relationship with FOB price, taxes and GAC oligopoly. The study recommended diversification and increasing non-oil exports in order to reduce the impact of the deficit in trade balance and encouraged local processing of agro-based raw materials to enhance the exports and take advantage of value added.
\end{abstract}

\section{KEY WORDS}

Gross Domestic Product (GDP), FOB price, GAC oligopoly, multiple regression analysis, oil exports, gum Arabic, sesame, cotton.

Export is an engine of growth and development because it integrates the various economic sectors and services together (FAO 2001). The low attention given to the development of the agricultural sector had resulted in its reduced contribution to the GDP from $49.8 \%$ in 1999 down to $31.1 \%$ in 2009 (Table 1).

This reduction takes place despite the increase in the value of agricultural GDP and the entry of other sectors such as the service sectors (transport, communications, trade, real estate, finance, insurance, etc.). The service sector contributed about $45.1 \%$ of GDP, and the industrial sector (electricity, water, mining, building and construction) contributed about $23.8 \%$ of the total GDP in 2009. Sudan being a developing country attempted to increase the national income to improve the living conditions of citizens by relying on exports of oil and other (Abdul-Karim, 2002).

The agricultural sector dominated the export earning of Sudan between $1950-1999$ (Ministry of Foreign Trade). By1999 with the advent of oil exports the dependence turned into oil sector. The agricultural export structure has been based on a limited number of primary commodities, mostly produced in the traditional sector. This included sesame, Gum Arabic, sunflower, sorghum, rosella, sena-makka, and live animals. The export of the modern irrigated sector products such as cotton and ground nut has been limited and declining (Ministry of Agriculture and Forestry).

The dismal performance of agricultural exports was caused by many difficulties such as low productivity, high production cost, high competition of exporting countries, and the multiplicity of duties and taxes (Soleman, 2007). 
Oil exports became at the top of the list of Sudanese exports, as it has contributed $91.5 \%$ on average during $2005-2009$. Non-oil exports contributed about $8.5 \%$ of which crops $4.4 \%$, livestock $1.8 \%$, manufacturing $0.4 \%$, minerals $1.1 \%$, and other exports $0.8 \%$.

Table 1 - Gross Domestic product of Sudan and contribution of agriculture during 1999-2009

\begin{tabular}{|c|c|c|c|c|c|}
\hline \multirow{2}{*}{ year } & \multicolumn{2}{|c|}{ Gross Demestic product (GDP) } & \multicolumn{2}{c|}{ Agricultural GDP } & \multirow{2}{*}{$\begin{array}{c}\text { Share of agricultral GDP } \\
\text { in total GDP \% }\end{array}$} \\
\cline { 2 - 5 } & Value( SDG billion) & Growth rate $\%$ & Value( SDG billion) & Growth rate \% & 49.8 \\
\hline 1999 & 124.3 & 6 & 6.1 & 8.5 & 46.4 \\
\hline 2000 & 134.6 & 8.3 & 6.2 & 0.8 & 45.6 \\
\hline 2001 & 143.2 & 6.4 & 6.5 & 4.7 & 46 \\
\hline 2002 & 152.4 & 6.5 & 7 & 7.3 & 45.6 \\
\hline 2003 & 161.7 & 6.1 & 7.3 & 4.5 & 44.5 \\
\hline 2004 & 172.3 & 7.2 & 7.7 & 7.2 & 39.6 \\
\hline 2005 & 64.3 & 8.1 & 7.5 & 8.3 & 36.8 \\
\hline 2006 & 80 & 9.3 & 8.1 & 2.4 & 36.2 \\
\hline 2007 & 90.3 & 10.5 & 8.6 & 7.7 & 31 \\
\hline 2008 & 120.7 & 7.8 & 8.6 & 6.7 & 31.1 \\
\hline 2009 & 148.1 & 6.1 & 8.6 & & \\
\hline
\end{tabular}

${ }^{*}$ At constant 1981/82.

Source: Bank of Sudan, Annual Report.

There are a number of challenges that face the dependence of the economy of Sudan on oil exports. Firstly, oil is a non- renewable resource and is expected to deplete one day in future. Secondly, most of the present oil fields are found in the South, and with the separation of the Southern part, the North will lose at least $75 \%$ of the oil revenue. Hence, the only way for Sudan economy to prosper and flourish is its dependence on agriculture and other related sectors (Salih, 2009).

Dependence on oil threatens the economy as its world prices are unstable, and the possibility of depletion of oil resources in the long run, available agricultural resources (crops and the livestock) had not been tapped yet.

Declining relative contribution of agricultural exports from $86 \%$ in $1995-1999$ to $6.2 \%$ in 2005-2009 of whole exports revenue.

\section{MATERIALS AND METHOD OF RESEARCH}

Descriptive method:

Multiple regression analysis. Can be multiple regression analysis to test the hypothesis of knowledge of the relationship between the dependent variable and two or more independent variables, the regression analysis is the most commonly used in various fields of science because it describes the relationship between the variables in the form of equations. (Gujarati, 1995). Regression analysis method to estimate the main determinant factors affecting exports of selected commodities of Sudan.

Model can be written as follows:

$$
\begin{gathered}
y_{i}=b_{0}+b_{1} x_{1 i}+\ldots \ldots+b_{k} x_{k i}+e \\
\text { Or } \\
y_{i}=b_{0}+b_{1} x_{1 i}+b_{2} x_{2 i}+u_{i}
\end{gathered}
$$

Models under study:

Sesame exports model. Variables that are related to exports of sesame crop world prices, produced quantities, cultivated area, and policy of economic liberalization issued on the sesame, the impact of entry of oil and time on the exports of sesame.

A linear form has been chosen since it expresses the trade function better than a nonlinear form. The non- linear form such a Cobb-Douglass function is more related to agricultural production functions. 
Multiple regression models have been applied and the regression equation is:

$$
s e_{t}=b_{0}+b_{1} w p s_{t}+b_{2} q p s_{t}+b_{3} \text { cults }_{t}+b_{4} l i b_{t}+b_{5} o i l_{t}+b_{6} t_{t}+e
$$

Where:

- $\mathrm{Se}_{\mathrm{t}}$ : the dependent variable represents the quantity exported from sesame.

The independent variables are:

- wps: $_{\mathrm{t}}$ : global prices in US\$ metric tons for crop sesame

- $\mathrm{qps}_{\mathrm{t}}$ : quantities produced metric tons of sesame crop

- cults $_{\mathrm{t}}$ : cultivated area by feddan of sesame crop

- lib: the impact of the policy of economic liberalization on the sesame crop (Dummy variable).( $\mathrm{Lib}=1$, non lib $=0$ )

- oilt: the impact of entry of oil (Dummy variable). (Entry of oil=1, before oil=0)

- $\mathrm{t}_{\mathrm{t}}$ : time

Cotton exports model. Variables that are related to the exports of cotton are the world prices, quantities produced, cultivated area, policy of economic liberalization issued on the impact of the entry of oil on cotton exports.

The specified regression equation model is:

$$
c e_{t}=b_{0}+b_{1} w p c_{t}+b_{2} q p c_{t}+b_{3} \text { cultc }_{t}+b_{4} \text { lib }_{t}+b_{5} \text { oil }_{t}+e
$$

Where:

- $\mathrm{Ce}_{\mathrm{t}}$ : the dependent variable represents the amount of exported cotton.

The independent variables are:

- $\quad$ wpc $_{\mathrm{t}}$ : global prices thousands of dollars to cotton crops

- qpc $_{\mathrm{t}}$ : quantities produced thousands of tons of cotton

- cultct: cultivated area by feddan of cotton crop

- lib $\mathrm{t}_{\mathrm{t}}$ the impact of the policy of economic liberalization on the cotton crop (Dummy variable). ( $\mathrm{Lib}=1$, non lib=0)

- oilt: the impact of entry of oil (Dummy variable). (Entry of oil=1, before oil=0)

Gum Arabic exports model. The Gum Arabic exports model is related to the world prices, quantities produced of Hahsab, stocks, taxes, GAC oligopoly and time on the exports of gum Arabic.

The specified regression equation model is:

$$
g A e_{t}=b_{0}+b_{1} w p g A_{t}+b_{2} q p h_{t}+b_{3} \operatorname{stkg} A_{t}+b_{4} t x g A_{t}+b_{5} o l i g g A_{t}+b_{6} t_{t}+e
$$

Where:

- $\mathrm{gAe}_{\mathrm{t}}$ : the dependent variable represents the quantity exported from Gum Arabic.

The independent variables are:

- wpgA $_{t}$ : global prices thousands of dollars to harvest gum Arabic

- $\mathrm{qph}_{\mathrm{t}}$ : quantities produced thousands of tons of crop gum Arabic

- stkgAt : stocks of crop gum Arabic

- $\operatorname{txgA}_{\mathrm{t}}$ : taxes of crop gum Arabic

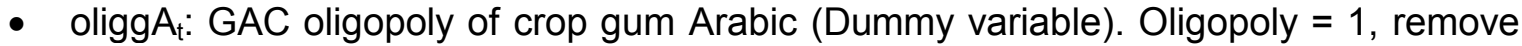
oligopoly $=0$.

- $\mathrm{t}_{\mathrm{t}}$ : time

\section{RESULTS OF STUDY}

Salient features of Sudan economy. Table (2) covers the period from 1999 to 2009. GDP increased from 14.8 SDG billion for the period 1999-2004 to 23.7 SDG billion for the period 2005-2009, with an increase of $60 \%$ due to the increase in agricultural GDP and 
exports. The table also shows that the average contribution of the agricultural sector in GDP has fallen from $46.2 \%$ to $34.5 \%$ by $11.7 \%$ during the same periods as a result of the evolution of the other sectors.

Exports of Sudan are composed of oil and non-oil exports. The latter is composed of agricultural, manufacturing and mining products. Despite an increase in the values of agricultural exports from 1.02 SDG billion to 1.11 SDG billion by $8.9 \%$, its contribution to the non-oil exports has fallen by $9.3 \%$ due to the decrease in the quantities exported. As known, the marked increase in total export revenues from 5.2 SDG billion 1999-2004 to 19.4 SDG billion 2005-2009, with an increase of $273 \%$ was mainly related to the entry of oil and derivatives into the exports list of Sudan.

Table 2- Salient features of Sudan economic performance during 1999-2009

\begin{tabular}{|l|c|c|c|}
\hline \multicolumn{1}{|c|}{ Year } & $\begin{array}{c}1999-2004 \\
\text { SDG billion }\end{array}$ & $\begin{array}{c}2005-2009 \\
\text { SDG billion }\end{array}$ & Increase \% \\
\hline GDP & 14.812 & 23.70 & 60 \\
\hline Agricultural GDP & 6.843 & 8.182 & 19.6 \\
\hline Share of agricultural GDP in national GDP (\%) & 46.2 & 34.5 & -11.7 \\
\hline Exports & 5.2 & 19.4 & 273 \\
\hline Non-oil exports & 1.2 & 1.5 & 22.2 \\
\hline Agricultural exports & 1.02 & 1.11 & 8.9 \\
\hline Agricultural exports in non -oil exports (\%) & 84.6 & 75.3 & -9.3 \\
\hline
\end{tabular}

Source: Bank of Sudan (Annual Reports), Ministry of Agriculture and Forestry (Agric, Statistics department).

Share of agricultural exports in agricultural (GDP). Table (3) illustrates the limited contribution of agricultural exports to agricultural GDP during 1999-2009. This was due to several reasons including smuggling of some goods such as gum Arabic, camels and gold and absence of information on border trade. In 2001, agricultural export earnings deteriorated due to the decline in exports of sheep as result of Arab countries (Saudi Arabia) suspicion of animals being infected with Rift Valley fever. The share of agricultural exports in agricultural GDP varied between $10.5 \%$ in 2007 as minimum to $17 \%$ in 2004 as maximum.

Table 3 - Share of agricultural exports in agricultural (GDP) during 1999-2009

\begin{tabular}{|c|c|c|c|}
\hline Year & $\begin{array}{c}\text { Agricultural GDP } \\
\text { SDG billion }\end{array}$ & $\begin{array}{c}\text { Agricultural exports } \\
\text { SDG billion }\end{array}$ & $\begin{array}{c}\text { Share of agric. Exports } \\
\text { in agric. GDP (\%) }\end{array}$ \\
\hline 1999 & 6.2 & 1 & 16.1 \\
\hline 2000 & 6.2 & 0.9 & 14.5 \\
\hline 2001 & 6.5 & 0.6 & 9.2 \\
\hline 2002 & 7 & 0.9 & 12.9 \\
\hline 2003 & 7.3 & 1 & 13.7 \\
\hline 2004 & 7.7 & 1.3 & 17 \\
\hline 2005 & 7.5 & 1.2 & 16.6 \\
\hline 2006 & 8.1 & 1.1 & 10.5 \\
\hline 2007 & 8.6 & 0.9 & 11.6 \\
\hline 2008 & 8.6 & 1 & 11.6 \\
\hline 2009 & 8.6 & 1 & \\
\hline
\end{tabular}

Source: Bank of Sudan (Annual Reports), Ministry of Agriculture and Forestry (Agric, Statistics department).

Share of oil and non- oil exports of Sudan during 1999-2009. From Table (4) the share of oil exports increased rapidly from 35\% of total exports revenue of Sudan in 1999 to $91 \%$ in 2009 , with variation between the years. These increases were tied to increases in quantities exported of oil and associated variation in oil prices during the period under study. Alternatively, as expected, the share of the non-oil exports indicated the opposite side of the oil exports share trend. The share of non-oil exports declined sharply from $65 \%$ to $9 \%$ of the total exports revenues of Sudan during 1999-2009. The fluctuations in exports share were also reflected in the table. It was noted that the increases in the exports values in the non-oil commodities were not enough to overcrowd the effect of the changes that took place in the oil exports earnings values and its respective share in the total exports of the Sudan. 
Table 4 - Share of oil and oil-non exports of Sudan during the period 1999-2009

\begin{tabular}{|c|c|c|c|}
\hline Year & Oil exports (\%) & Non- oil exports (\%) & Total exports (\%) \\
\hline 1999 & 35 & 65 & 100 \\
\hline 2000 & 75 & 25 & 100 \\
\hline 2001 & 81 & 19 & 100 \\
\hline 2002 & 78 & 22 & 100 \\
\hline 2003 & 81 & 19 & 100 \\
\hline 2004 & 82 & 18 & 100 \\
\hline 2005 & 87 & 13 & 100 \\
\hline 2006 & 90 & 10 & 100 \\
\hline 2007 & 95 & 5 & 100 \\
\hline 2008 & 95 & 5 & 100 \\
\hline 2009 & 91 & 9 & \\
\hline
\end{tabular}

Source: Bank of Sudan, Annual Reports.

(\%)

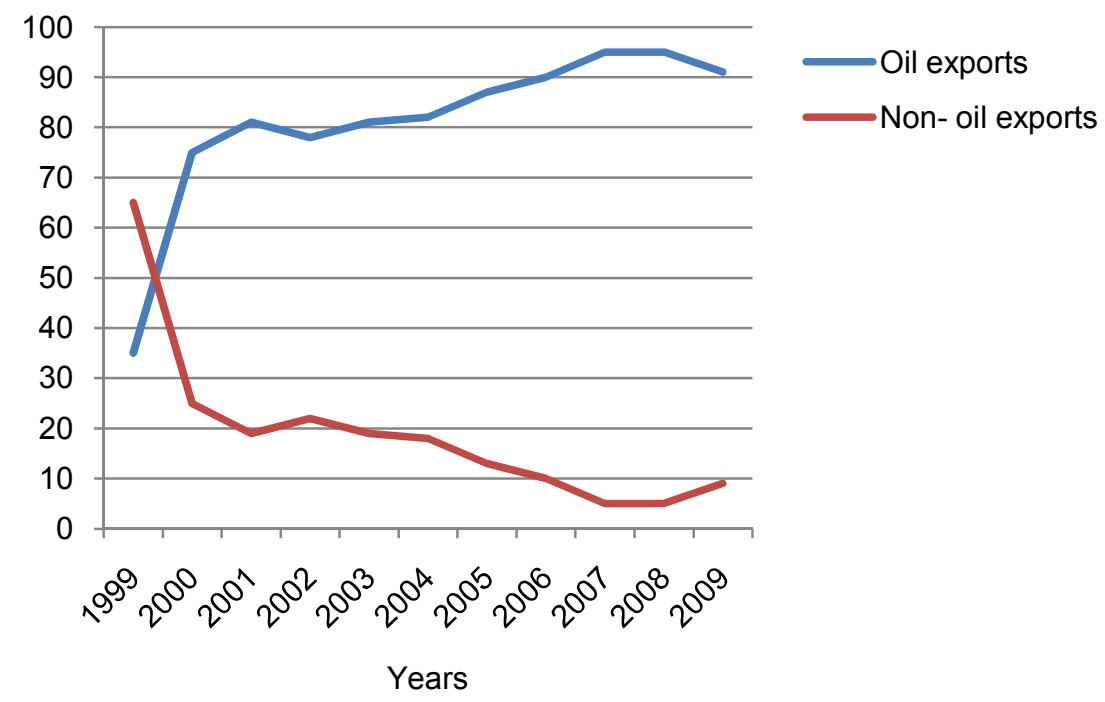

Figure 1 - Percentage share of oil and non- oil exports in Sudan during the period 1999-2009. Source: Bank of Sudan, Annual Reports.

Trade balance. Sudan experienced negative balance of trade throughout the period 1990-2009, except for few years after the entry of oil exports. Table (5) gives the trade balance for the years 1990-2009. From the table the exports of Sudan ranged between $\$ 305$ million in 1991 as minimum to $\$ 620.2$ million in 1996 as maximum value. On the other side, the imports ranged between $\$ 618.5$ million as minimum in 1990 and $\$ 1184.5$ million as maximum in 1995. Consequently, the trade balance ranged from negative $\$ 244.4$ million in 1990to negative \$1136.5 million in 1998.

When looking into the period after the entry of the oil exports (1999-2009), the total exports of Sudan galloped several folds. The exports ranged between $\$ 780$ million in 1999 as minimum to $\$ 11670.504$ million in 2008 as maximum. Similarly, the imports galloped between \$ 1414.9 million in 1999 as minimum to $\$ 9690.918$ million as maximum. The consequent trade balance performance ranged between negative $\$ 42416.93$ million in 2006 to positive \$113.2 million in 2001.

It was noted that the entry of oil exports availed large foreign exchange earnings which helped in increasing the demand for imported goods that was not possible before the entry of oil exports.

From table (5) it was found that the balance of trade before the entry of oil was indicating a deficit value during 1990 to 1999 due to rising imports and declining exports earnings. Imports included high imports of oil products. By the year 2000 and 2001, the trade balance recorded a surplus for the first time, and partially attributed to the improvement in the balance trade to reduction in oil imports. The years 2002-2006 indicated resumption to the 
deficit in the balance of trade again. This was due to the hard currency generated by exports of oil which allowed higher imports of needed commodities. However, the increased exports in 2007 and 2008 turned the deficit into a surplus in the balance of trade.

Table 5 - Balance of trade during the period 1990-2009 in US\$ million

\begin{tabular}{|c|c|c|c|c|c|}
\hline year & $\begin{array}{c}\text { Oil exports } \\
\text { (US\$ million) }\end{array}$ & $\begin{array}{c}\text { Non-oil exports } \\
\text { (US\$ million) }\end{array}$ & $\begin{array}{c}\text { Total exports } \\
\text { (US\$ million) }\end{array}$ & $\begin{array}{c}\text { Imports } \\
\text { (US\$ million) }\end{array}$ & $\begin{array}{c}\text { Trade balance } \\
\text { (US\$ million) }\end{array}$ \\
\hline 1990 & 0 & 374.1 & 374.1 & 618.5 & -244.4 \\
\hline 1991 & 0 & 305 & 305 & 890.3 & -585.3 \\
\hline 1992 & 0 & 319.3 & 319.3 & 820.9 & -506.6 \\
\hline 1993 & 0 & 417.3 & 417.3 & 944.9 & -527.6 \\
\hline 1994 & 0 & 523.9 & 523.9 & 1161.5 & -637.6 \\
\hline 1995 & 0 & 555.7 & 555.7 & 1184.5 & -628.8 \\
\hline 1996 & 0 & 620.2 & 620.2 & 1504.4 & -884.2 \\
\hline 1997 & 0 & 594.2 & 594.2 & 1579.7 & -985.5 \\
\hline 1998 & 0 & 595.7 & 595.7 & 1732.2 & -1136.5 \\
\hline 1999 & 275.9 & 504.2 & 780.1 & 1414.9 & -634.8 \\
\hline 2000 & 1350.8 & 455.9 & 1806.7 & 1552.7 & 254 \\
\hline 2001 & 1376.6 & 322.1 & 1698.7 & 1585.5 & 113.2 \\
\hline 2002 & 1510.857 & 438.258 & 1949.115 & 2446.384 & -497.269 \\
\hline 2003 & 2047.705 & 494.471 & 2542.176 & 2881.915 & -339.739 \\
\hline 2004 & 3100.486 & 677.278 & 3777.764 & 4075.230 & -297.466 \\
\hline 2005 & 4187.360 & 636.918 & 4824.278 & 6756.820 & -1932.542 \\
\hline 2006 & 5087.211 & 569.357 & 5656.568 & 8073.498 & -2416.930 \\
\hline 2007 & 8418.528 & 460.722 & 8879.250 & 8775.457 & 103.793 \\
\hline 2008 & 11094.111 & 576.393 & 11670.504 & 9351.540 & 2318.964 \\
\hline 2009 & 7131.255 & 702.441 & 7833.696 & 9690.918 & -1857.222 \\
\hline
\end{tabular}

Source: Bank of Sudan, Annual Reports.

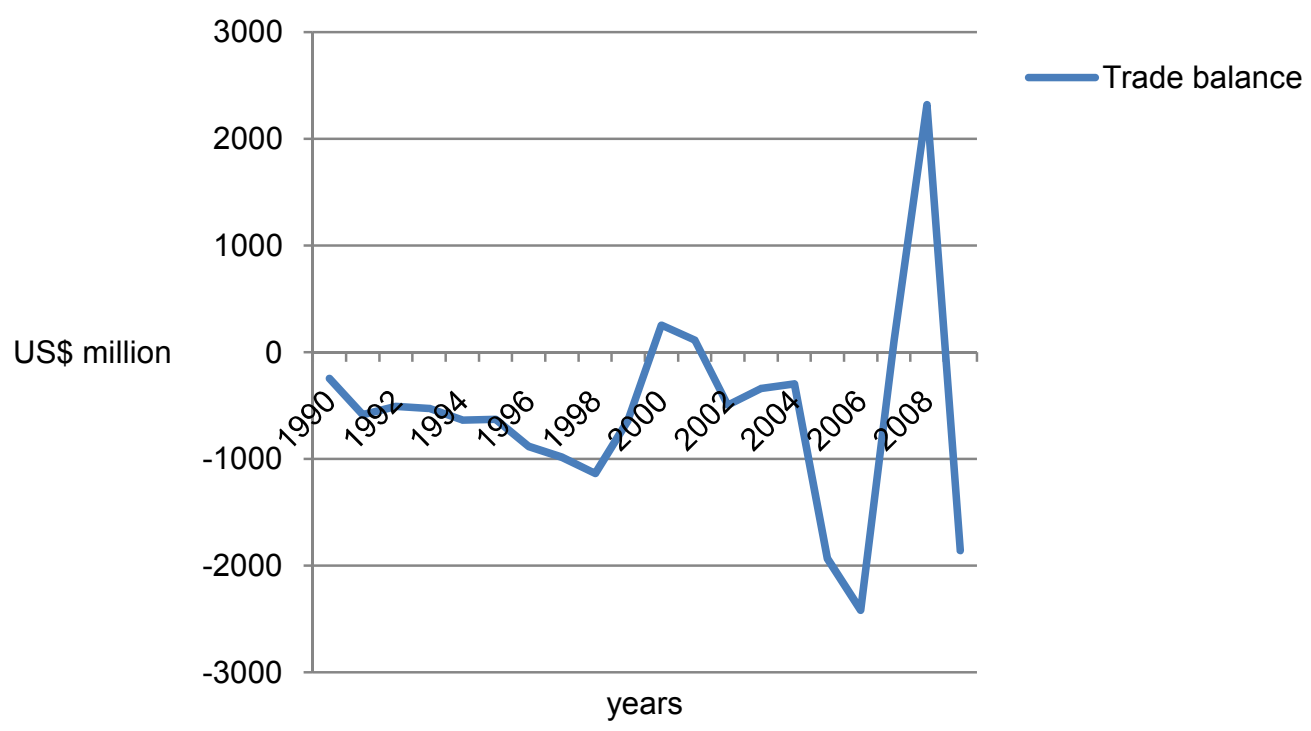

Figure 2 - Trade balance in Sudan during the period 1990-2009. Source: Bank of Sudan, Annual Reports.

Exports of Sudan. Oil products accounted for a large proportion of the total exports revenues of Sudan during the last ten years table (6). Despite the extensive resource base and comparative advantage enjoyed by the Sudan in the field of agricultural commodities in both its production of plants and animals these exports did not exceed $6.2 \%$ of the total exports revenue on average over the years 2005-2009. Oil exports revenue accounted to over four times and more of the non-oil exports during the two consecutive periods. The exports of the manufacturing and mining products experienced a decline in recent years. 
Table 6- Contribution of Sudanese exports during the period $1990-2009$ in percentages

\begin{tabular}{|l|c|c|c|c|}
\hline Item Year & $1990-1994(\%)$ & $1995-1999(\%)$ & $2000-2004(\%)$ & $2005-2009(\%)$ \\
\hline Oil exports & - & $*$ & 79.1 & 91.5 \\
\hline Non-oil exports & 100 & 100 & 20.9 & 8.5 \\
\hline Crops \&forest exports & & & 11.8 & 4.4 \\
\hline Livestock exports & & & 4.2 & 1.8 \\
\hline Manufacturing exports & & & 1.6 & 0.4 \\
\hline Mining exports & & & 2.6 & 1.1 \\
\hline Others exports & & & 0.7 & 0.8 \\
\hline
\end{tabular}

*oil exports began in 1999 with a value of US\$275.885 thousand.

Source: Bank of Sudan, Annual Reports.

Non- oil exports. Table (7) covers the period from 1990-2009, where the contribution of crops exports declined from $56.2 \%$ during $2000-2004$ to $50.9 \%$ during $2005-2009$. The share of livestock exports dropped from $21.2 \%$ to $19.5 \%$ during the same periods. The share of the manufacturing exports decreased slightly from $7.5 \%$ to $6 \%$ due to reduced raw materials and spare parts, while that of mineral exports rose from $12 \%$ to $15.5 \%$ due to increased exports of gold.

Table 7- Percentage contribution of non-oil export sectors during 1990-2009

\begin{tabular}{|l|c|c|c|c|}
\hline Year & \multirow{2}{*}{ I990-1994 (\%) } & 1995-1999 (\%) & $2000-2004(\%)$ & $2005-2009(\%)$ \\
\hline Crops \& forest exports & & & 56.2 & 50. \\
\hline Livestock exports & & & 21.2 & 19.5 \\
\hline Manufacturing exports & & & 7.5 & 15. \\
\hline Mining exports & & & 3. & 8.1 \\
\hline Other exports & & 100 & 100 & 100 \\
\hline Total & 100 & 100 & & \\
\hline
\end{tabular}

Source: Bank of Sudan, Annual Reports.

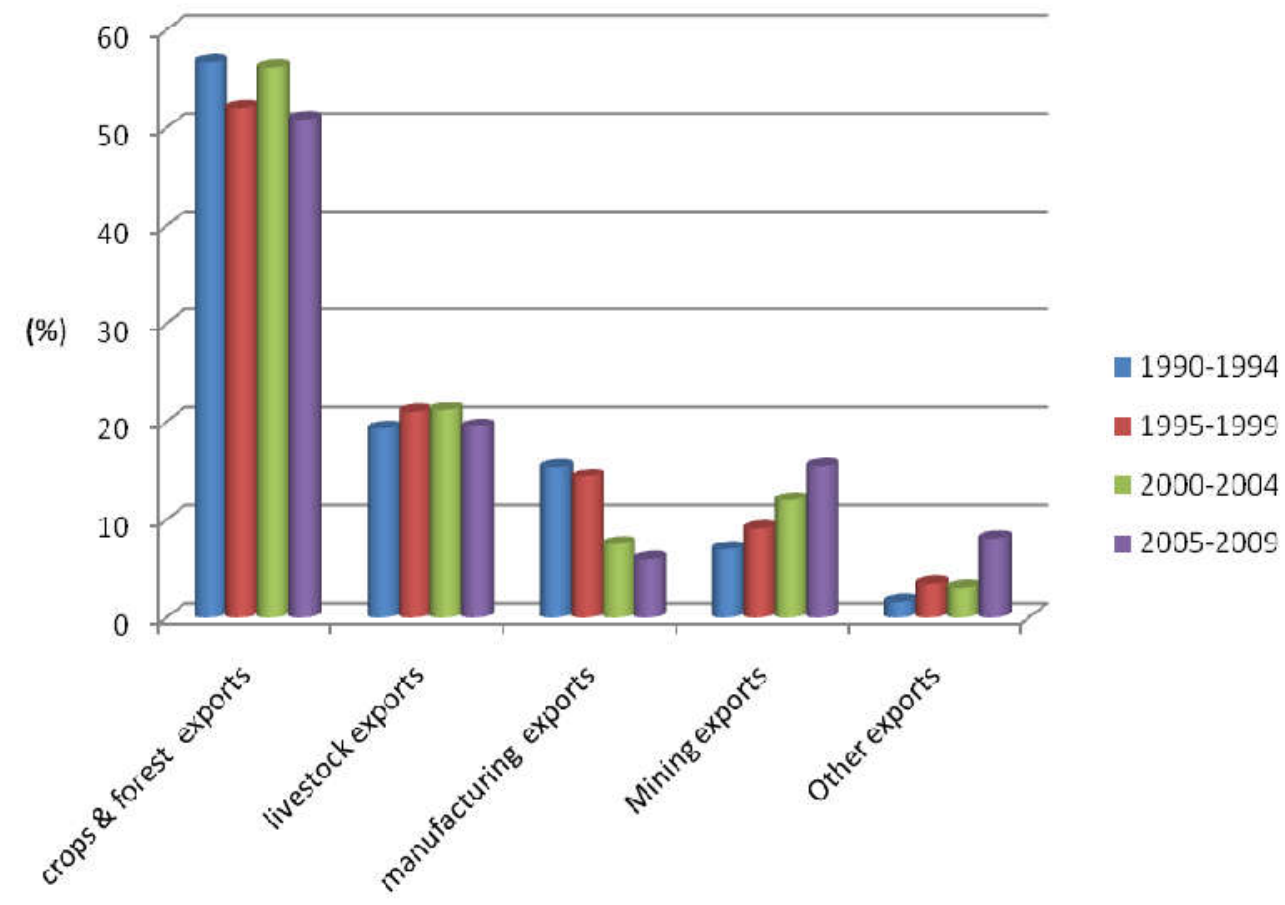

Figure 3 - Contribution of non-oil exports sectors to total exports of Sudan during the period (19902009 ) in percentages. Source: Bank of Sudan, Annual Reports. 
Multiple Regression Analysis Results:

Sesame export function. The model specification for sesame was made for exports for the period 1970-2009. The exports model regressed sesame exports quantities as dependent variable against independent variables that included FOB prices, supply of sesame, cultivated area, liberalization policy, oil and time. Table (8) gives the results with the adjusted $\mathrm{R}^{2}$ of $73 \%$ reflecting the extent of the variables captured and explained by the specified model. The F value of 18.5 indicated the overall significance of the model.

Table 8 - Regression results of sesame exports in Sudan during 1970-2009

\begin{tabular}{|l|c|c|c|}
\hline \multicolumn{1}{|c|}{ Variables } & B & T value & Significance \\
\hline Constant & 107.292 & 4.383 & 0.000 \\
\hline FOB Price & -0.05457 & -2.707 & 0.011 \\
\hline Production & -0.165 & -1.744 & 0.091 \\
\hline Cultivated area & 0.01956 & 2.274 & 0.030 \\
\hline Liberalization policy & 54.195 & 2.175 & 0.037 \\
\hline Oil & 41.509 & 2.408 & 0.022 \\
\hline Time & -1.089 & -.902 & 0.374 \\
\hline
\end{tabular}

Dependent Variable: Sesame Exports

Adjusted R2 $=73 \%$

$F=18.5$

The exports of sesame model depicted a significant positive relationship between sesame exports and oil. As oil increased practicing by one year through time, there was an associated increase in the exports of sesame by 41.5 metric tons. However, opposite to expectation. There was a significant but negative relationship between world price (FOB) and exports of sesame. This implied a demand relationship, which indicated that an increase in world prices of sesame by US $\$ 1000$ per metric ton will decrease the exports of sesame by 0.05 tons.

The relationship between both production and time with sesame exports were negatively and significant, during the period of analysis. As the production of sesame increases by one ton per Fadden, the exports of sesame would decrease by 0.16 metric tons per year, and similarly, as the time of sesame reducing it by 1 metric tons per year.

Cultivated area and liberalization policy have a positive significant effect on the exports of sesame, as the cultivated area of sesame increase by one Fadden per year that lead to increase by 0.02 metric tons per year. As Liberalization policy increased by one year through the time the exports of sesame would increase by 54.2 metric tons per year.

Cotton export function. The model of the exports of cotton was formulated by regressing its exports quantities for the period 1970-2009 against FOB prices, supply of cotton, cultivated area, liberalization policy and oil. Table (9) gives the results of the regression analysis with the adjusted $R^{2}$ of $70 \%$ reflecting the capacity of the model in explaining that percentage of the reality modeled. The $F$ value of 18.2 indicated the overall significance of the model.

Table 9 - Regression results of cotton exports of Sudan during 1970-2009

\begin{tabular}{|l|c|c|c|}
\hline \multicolumn{1}{|c|}{ Variables } & B & T value & Significance \\
\hline Constant & 211.199 & 5.405 & .000 \\
\hline FOB Price & -10.017 & -7.850 & .000 \\
\hline Production & 0.05479 & .701 & $.488^{*}$ \\
\hline Cultivated area & 0.03886 & .794 & $.433^{*}$ \\
\hline Liberalization policy & 13.377 & .610 & .546 \\
\hline Oil & -48.462 & -2.476 & .018 \\
\hline
\end{tabular}

Dependent Variable: Cotton Exports.

${ }^{*}$ Multicolinearity between two variables.

Adjusted R 2= 70\%

$F=18.2$ 
From the results, both the FOB prices and oil had a negative and significant relationship with exports of cotton during the period of analysis. As the FOB price of cotton increases by US $\$ 1000$ per metric ton the exports of cotton decreases by 10 metric tons, this implies a demand relationship, and similarly, as for the oil reducing cotton exports by 48.4 metric tons per year.

Gum Arabic export function. The model of the exports of gum Arabic was formulated by regressing its exports quantities for the period 1970-2009 against FOB prices, supply of gum Arabic, gum-stocks, GAC oligopoly, and taxes and time. Table (10) gives the results of the regression analysis with the adjusted $R^{2}$ of $77.8 \%$ reflecting the capacity of the model in explaining that percentage of the reality modeled. The $\mathrm{F}$ value of 30 indicated the overall significance of the model.

Table 10 - Regression results of gum Arabic exports of Sudan during 1970-2009

\begin{tabular}{|l|c|c|c|}
\hline \multicolumn{1}{|c|}{ Variables } & $\mathrm{B}$ & T value & Significance \\
\hline Constant & 603.18 & 1.415 & .167 \\
\hline FOB Price & -5.179 & -5.245 & .008 \\
\hline Taxes & -21.321 & -.863 & .039 \\
\hline GAC oligopoly & -14.371 & -.069 & .095 \\
\hline Time & 4.978 & 4.661 & .000 \\
\hline Hahsab supplies & 1.850 & 6.744 & .000 \\
\hline Stocks & 1.744 & 7.853 & .000 \\
\hline
\end{tabular}

Dependant Variable: Gum Arabic Exports.

Adjusted $R^{2}=77.8 \%$

$F=29.97$

From the results, both the supply and the stocks of gum Arabic had a positive and significant relationship with exports of gum Arabic during the period of analysis. As the supply of gum Arabic increases by one metric ton the exports of gum increases by 1.85 metric tons, and similarly, as the stocks of gum increases by one metric, the exports increases by 1.744 metric tons. It seemed that the stocks give a buffer to supplement the needed deficits of the supply in question.

As expected, the taxes had negative and significant effect on exports of gum Arabic products reducing it by 21.3 metric tons per year. The FOB prices had a negative and significant effect on the exports of gum decreasing it by 5 tons per US $\$ 1000$ per metric ton. This negative relationship could be interpreted as a demand function rather than a supply function. However, it may also be interpreted that since GAC used to adopt irrational pricing policies, the response of the importing countries was negative, and hence the increase in prices would reduce the quantities exported. The relationship between GAC oligopoly and the exports of gum Arabic was negative. As oligopoly continues on by one year, the exports of gum drop by 14.37 metric tons per year. Time seemed to have a significant and positive effect on gum Arabic exports.

\section{DISCUSSION}

The volatility that characterized the world oil prices is reflected in the ability of oilproducing countries to continue in development projects. It weakens their ability to manage their institutions and their development programs. The phenomenon of the Dutch Disease evolves from the increase in oil revenues in oil producing countries leading to a rise in their exchange rate and in turn to a weakening of their non-oil private agriculture and industry products. Furthermore, the oil sector is characterized by sophisticated technology and high skills which are not available to the people of the producing countries (OPEC, 2008). In this respect the UN reports indicate that oil-producing countries suffer from the concentration of wealth in the hands of a few people, which results in the aggravation of Poor distribution of income in those countries.

We find that the contribution of exports of agricultural and livestock of the total exports for 1998 amounted to $45 \%$ and $25 \%$ respectively compared to 2009 , the proportion of these 
exports $3 \%$ and $2.5 \%$ and oil exports increased $91.5 \%$ and above it is clear that symptoms of Dutch disease has become more pronounced, threatening non-oil sectors as a whole.

\section{CONCLUSIONS}

The agriculture sector is a principal sector in the Sudanese economy; the importance of the agriculture sector is rooted in its being the main source of income and livelihood for the majority of the population of Sudan.

Before 1999, Sudan's economy was based largely on agriculture as a source of foreign exchange earnings. After the exploration and exports of oil products in 2000, the earnings of agriculture exports dropped significantly. This situation requires the Increase non-oil exports to reduce the impact of the deficit in the current balance of trade that resulted from increased imports, due to increased in the hard currencies revenues of oil exports, Direct oil revenues to contribute in development of production and exports of the agricultural commodities and other non-oil commodities, Cut taxes to reduce smuggling of commodities to neighboring countries for re- export and Focus on processed raw material exports rather than exports of raw materials to take advantage of value-added.

\section{REFERENCES}

1. Abdul-Karim, I. (2002). Implication of the URAA on Sudan's Agricultural Trade. Berlin Journal, Series No 2, Berlin, Germany.

2. Bank of Sudan, Khartoum. (2009). Forty-seven Annual Report. Khartoum, Sudan.

3. Food and Agriculture Organization of the United Nations. (FAO).

4. Ministry of Agriculture and Forestry. Department of Agricultural Economics, Year Book of Statistics, Khartoum.

5. Ministry of Foreign Trade. Exports Reports 1990-2009.

6. N. Gujarati. Basic Econometrics.Third Edition (1995). USA.(2001). Multilateral trade negotiations on agriculture. Basic information the user folder first and second volume. Rome, Italy.

7. Organization of Petroleum Exporting Countries (OPEC) (2008). Annual report.

8. Salih, A. A. and others. (2009). Assessing Sudan's Export Diversification potential in Agricultural Products. Ministry of Foreign Trade and Sudan EPA Negotiations and Implantation Support (SENIS). Khartoum, Sudan.

9. Soleman, A.E. (2007). A working paper entitled the reality of non-oil exports of Sudan. National Centre for Research, Journal of Banking. Sudan. 